\title{
The Effect of Pedagogical Competence and Creativity of Teaching Mathematics Teachers on Students' Creative Thinking Abilities
}

\author{
Anggia Pusparona \\ ${ }^{1}$ Mathematics Education Department, Post Graduate, Universitas Jambi-Indonesia \\ Email: anggiapuspa11@gmail.com \\ Nizlel Huda \\ ${ }^{2}$ Mathematics Education Departments, Education, and Teacher Training Faculty, Universitas Jambi-Indonesia \\ Email: nizlel@yahoo.com \\ Zurweni \\ ${ }^{3}$ Science Education Departments, Education, and Teacher Training Faculty, Universitas Jambi-Indonesia \\ Email: nonichem@gmail.com
}

DOI: 10.31364/SCIRJ/v8.i10.2020.P1020812

http://dx.doi.org/10.31364/SCIRJ/v8.i10.2020.P1020812

\begin{abstract}
This study aims to describe the competence of pedagogy, the creativity of mathematics teachers in teaching, and their influence on students' creative thinking abilities. This research uses a quantitative approach involving 6 mathematics teachers and 40 students. Based on the data and discussion above it can be concluded that the pedagogical competence of teachers is dominated by the group with the category of "medium" as much as $65.6 \%$, the creativity of mathematics teachers in teaching is dominated by the group with the moderate category as much as $83.3 \%$ and the creative thinking abilities of students are at the low category, which is as much as $47.5 \%$. Based on the results of the $T$-test it appears that, obtained sig. for the influence of teacher pedagogical competence (X2) is 0.081 . The value $>0.05$, it means that pedagogical competence does not significantly affect students' creative thinking abilities. The value of sig, for teacher creativity on students 'creative thinking abilities, is equal to $0,000<0.05$, which means that mathematics teacher's creativity in teaching has a significant effect on students' creative thinking abilities.
\end{abstract}

Keywords: Pedagogic Competence, Mathematics Teacher's Creativity, Students' Creative Thinking Ability

\section{INTRODUCTION}

Teachers as the main actors in implementing educational programs in schools have a very important role to achieve educational goals. The teacher is one of the spearheads of the successful goals of education. Teachers are the most decisive component in the overall education system that must receive central, first, and foremost attention (Supranoto, 2015). For this reason, in creating a quality education process professional teachers are needed (Alghifari et al., 2016). According to
Indonesian law, one indicator of professional teachers is that they have pedagogical competence.

Pedagogical competence is the ability of teachers related to education, the educational process, the character of students, and the assessment of the educational process itself. According to Habibullah (2012), pedagogical competence is the ability to manage the learning process. These competencies include understanding students, designing and implementing learning, evaluating learning outcomes, and developing students to actualize their various potentials. According to Kurniawan \& Astuti (2017), pedagogic competence is the ability to manage to learn well. Thus, it is following the role of the teacher, which includes: educating, guiding, training, advising, making updates, being a model and role model, having a personality, researchers, encouraging creativity, generating views, doing routine workers, bringing stories, becoming actors, emancipator and conduct evaluation (Juhji, 2016). Hadi (2018) states that pedagogic competence is the ability of a teacher to manage the learning process of students and help, guide, and lead students. The learning process is essential to develop students' activities and creativity, through various interactions and learning experiences (Wahyuni, 2013).

According to research, pedagogical competence influences student learning habits (Lambok Simamora, 2014). Besides, pedagogical competence can also influence student learning outcomes in sociology subjects (Rasuli \& Rivaie, 2013), science subjects (Purnamawanti, Suliswiyadi, \& Nugroho, 2018), and economic literacy of students (Wulandari, 2012), also student motivation (Rahman, Mutiani, \& Putra, 2019). Pedagogic competence also influences the motivation and performance of

www.scirj.org

(C) 2020, Scientific Research Journal

http://dx.doi.org/10.31364/SCIRJ/v8.i10.2020.P1020812

This publication is licensed under Creative Commons Attribution CC BY. 
the teacher concerned (Supriyono, 2017), and (Sappaile, 2017). Thus it can be understood that the teacher's pedagogical competence has a positive impact on the learning process and outcomes. Thus, it is clear that a teacher's pedagogical competence impacts the quality of himself and the quality of his work, namely the implementation of the learning process. Therefore, a teacher ideally has good pedagogical competence.

In addition to teacher pedagogical competence, teacher creativity holds the key to arouse and develop students' creativity. A teacher, who wants to arouse creativity in his students, must first try so that he is creative. In general, creative teachers have been educated by creative people in an environment that supports it (Monawati \& Fauzi., 2018). Therefore, teacher creativity in managing learning is one form of demand as a teacher's professional staff (Febriandar, 2018).

Psychological creativity is the ability of a person to produce any composition, product, or idea that is new, and previously unknown to its creator (R.M, 1994). Creativity thinking or creative thinking, creativity is an act of thinking that produces creative ideas or ways of thinking that are new, original, independent, and imaginative. Creativity is seen as a mental process (Sagitasari, 2010). The Fakhriyani (2016) states that creativity is an ability that is not brought from birth but can be learned and developed so that this ability should be developed from an early age. The results of Sambada's (2012) study also state that there is a positive and significant relationship between student creativity and problem-solving skills. Because it can be understood that creativity is one of the potential possessed by every human being, including students and teachers.

One form of teacher creativity in teaching is in making learning media. The development of appropriate learning media by teachers (requires teacher creativity) can improve the quality of learning and improve teacher learning outcomes (Nurrita, 2018). Also, Juandi \& Sontani (2017) found that there is a positive influence of teacher's teaching creativity on student achievement. As for Febriandar (2018) found that teacher creativity is very influential on student motivation and learning outcomes. Creative teachers are not only good at decision making and dominating the classroom, but also experts in designing a teaching style that involves students in decision making so that students are active, varied and creative in each episode of learning (Wahyuni, 2013). As for you (2017) in his writing also mentioned that the role of the teacher in developing students' creative thinking abilities is very strategic so that the person should be optimized.

Based on some of the descriptions above, it can be understood that creativity is defined as the ability to create a new product, both truly new and which is a modification or change by developing things that already exist. If this is related to the creativity of the teacher, the teacher concerned creates a teaching strategy that is completely new and original (original creation), or it can be a modification of various existing strategies to produce a new form in implementing the teaching and learning process (Monawati \& Fauzi., 2018). The measurement of teaching creativity variables in this study includes 5 indicators as follows: 1) ability to think smoothly, 2) ability to think flexibly (3), 3) ability to think rationally, 4) ability to detail or elaborate, and 5) ability to assess or evaluate (Juandi \& Sontani, 2017).

Associated with the ability to think creatively, Nuriadin \& Perbowo (2013) defines as the ability of a person to find ideas or new ideas in solving problems using the previous experience they already have. The ability to think creatively is needed by humans in dealing with problems in their lives, creative thinking is generally obtained in the world of education (Tambunan, 2016). Sugilar (2013) emphasized that students' creative thinking skills could not develop properly if in the learning process the teacher did not actively involve students in concept formation, the learning methods used in schools were still conventional, namely learning that was still teacher-centered. Thus it is clear that the ability to think creatively is an ability that is very important to be developed and become the main capital for each individual in the problem-solving process. Besides, some experts also mentioned that the ability to think creatively is also a highlevel thinking ability (Musrikah, 2018).

Various attempts have been made to improve students' creative thinking abilities. These efforts involve the macro scale and micro scale. Macroscale in the form of national curriculum design and microscale in the form of a learning process. Related to the teacher's pedagogical competencies, the development of students' creative thinking abilities is carried out at the microscale, namely in the learning process. Efforts to improve the ability to think creatively through the learning process by applying certain learning models, for example, problem-based learning models (Siswono, 2004) and (Noer, 2013), through the implementation of project-based learning models (Rahmazatullaili, Zubainur, \& Munzir, 2017), the application of problem-solving learning (Nurjannah \& Irma, 2019), the development of teaching materials in the form of modules (Anggoro, 2015), through learning with constructivist approaches (Azhari \& Somakim, 2014). Besides, efforts to improve the ability to think creatively can also be done through the development of instruments (Moma, 2016).

Based on the description above, it can be understood that there is a link between the teacher's pedagogical competence, teacher's creativity, and students' creative thinking abilities. Therefore, the focus of this study is to find out how the influence of teacher pedagogical competence and teacher creativity in teaching on the creative thinking ability of students.

\section{RESEARCH METHOD}

This study uses a quantitative approach with a correlational method, which is to see the correlation of pedagogic competence and teacher creativity in teaching mathematics with students' creative thinking abilities. This research data collection uses a questionnaire to measure teacher pedagogic competence, an observation sheet to measure teacher creativity in teaching and tests to measure students' creative thinking abilities. Test 
instruments are arranged based on each indicator on each instrument. Before being used to capture data, all instruments were validated by experts, both construct and content. Thus there is no doubt about the data obtained in this study. The data obtained in the study are the scores. The maximum score for the pedagogic competency variable and the teacher's creative ability is 30 and the minimum score is 0 . As for the creative thinking variable, the maximum score is 50 (fifty) and the minimum score is 0 (zero). The scoring of each variable is based on indicators measured on the instrument. Based on the scores obtained, then analyzed to classify each variable in the "low", "medium" and "high" categories. In this study, involving 6 (six) mathematics teachers and 40 students. The data analysis is carried out with the help of SPSS.16 software, this is intended to ensure the accuracy of the data analysis.

\section{RESULT AND DISCUSS}

Based on data obtained from respondents using instruments that have been developed, data analysis is then performed. The first data analysis is done by classifying the ability level of each respondent based on the score scale obtained, namely in the category of "high", "medium" and "low". Based on this classification, the data obtained as in the following Table 1:

Table 1. Pedagogical Competence, Teacher Creativity and Creative Thinking Abilities of Students

\begin{tabular}{|c|c|c|c|c|}
\hline Aspect & Score & Number & $\begin{array}{l}\text { Percentage } \\
(\%)\end{array}$ & Category \\
\hline \multirow{4}{*}{$\begin{array}{l}\text { Pedagogic } \\
\text { competence }\end{array}$} & $21-30$ & 1 & 16,6 & High \\
\hline & $11-20$ & 4 & 65,8 & Moderate \\
\hline & $0-10$ & 1 & 16,6 & Low \\
\hline & Total & 6 & 100 & \\
\hline \multirow{4}{*}{$\begin{array}{l}\text { Teaching } \\
\text { creativity }\end{array}$} & $21-30$ & 0 & 0 & High \\
\hline & $11-20$ & 5 & 83,3 & Moderate \\
\hline & $0-10$ & 1 & 16,7 & Low \\
\hline & Total & 6 & 100 & \\
\hline \multirow{4}{*}{$\begin{array}{l}\text { Students' } \\
\text { creative } \\
\text { thinking } \\
\text { skills }\end{array}$} & $36-50$ & 6 & $15 \%$ & High \\
\hline & $18-35$ & 15 & $37,5 \%$ & Moderate \\
\hline & $0-17$ & 19 & $47,5 \%$ & Low \\
\hline & Total & 40 & 100 & \\
\hline
\end{tabular}

Based on Table 1 above, it can be seen that the pedagogical competence of teachers is dominated by the group with the category of "moderate", which is as much as $65.6 \%$, this indicates that in general, the pedagogical competence of mathematics teachers in SMA 6 Muaro Jambi is in the medium category. As for mathematics teachers with a low competency category of $16.6 \%$, followed by high abilities of $16.6 \%$. As for the variable of teaching creativity, information is obtained that in general the creativity of mathematics teachers in teaching is dominated by groups with medium categories as much as $83.3 \%$. Then followed by a low category group that is $16.6 \%$ and a group with a high category of $0 \%$. Besides, based on Table 1 it can also be seen that in general students' creative thinking abilities are in a low category, which is as much as $47.5 \%$, the medium category is as much as $37.5 \%$ and the high category group is as much as $15 \%$.

Furthermore, the score is analyzed to determine the correlation between variables. As for the results of data analysis with the help of SPSS 25 software, the output model summary is shown in table 2 below:

Table 2. Model Summary, Correlations between variables

\begin{tabular}{|c|c|c|c|c|}
\hline Model & $\mathrm{R}$ & $\begin{array}{c}\mathrm{R} \\
\text { Square }\end{array}$ & $\begin{array}{l}\text { Adjuste } \\
\text { d R Square }\end{array}$ & $\begin{array}{l}\text { Std. Error } \\
\text { of the } \\
\text { Estimate }\end{array}$ \\
\hline 1 & $893^{\mathrm{a}}$ & .797 & .792 & 1.159 \\
\hline
\end{tabular}

Based on the test summary model above, it appears that the $\mathrm{R}$ square value of 0.797 . It shows that the mathematics teacher's pedagogical competence and the teacher's creative ability to teach affect the level of students' creative thinking abilities by $79.7 \%$. The remaining $18.3 \%$ is influenced by other factors. Therefore it can be said that the teacher's pedagogical competence (X2), the teacher's creativity in teaching $(\mathrm{X} 1)$ has a strong enough influence on the students' creative thinking abilities.

Table 3. ANOVA Test Results (Test F) between variables

\begin{tabular}{|c|c|c|c|c|c|}
\hline \multicolumn{6}{|c|}{ ANOVA $^{-a}$} \\
\hline Model & $\begin{array}{l}\text { Sum of } \\
\text { Squares }\end{array}$ & Df & $\begin{array}{l}\text { Mean } \\
\text { Square }\end{array}$ & $\mathrm{F}$ & Sig. \\
\hline 1 Regression & 406.570 & 2 & $\begin{array}{r}20 \\
3.285\end{array}$ & $\begin{array}{r}1 \\
51.4 \\
12\end{array}$ & $000^{\mathrm{b}}$ \\
\hline Residual & 103.380 & 77 & $\begin{array}{r}1.3 \\
43\end{array}$ & & \\
\hline Total & 509.950 & 79 & & & \\
\hline
\end{tabular}

b. Predictors: (Constant), Pedagogic competency (X2), Teacher Creativity (X1)

Based on the ANOVA output table above, it can be seen that the sig values are obtained. in the $F$ test is 0,000 , which means $<0.05$. That means that the two variables of teacher pedagogical competence (X2), teacher creativity in teaching (X1) significantly together affect the students' creative thinking abilities. Besides, if it is based on the value of F-count and Ftable, then the value of F-count $=151.421$, while the F-table for $\mathrm{N}=80$ is 3.11. Thus Fcount $>$ Ftable, the hypothesis is accepted, 
namely that the teacher's pedagogical competence (X2), the teacher's creativity in teaching (X1) significantly together affects the students' creative thinking abilities.

Table 4. Coefficients Test Results (T-Test) between variables

\begin{tabular}{|c|c|c|c|c|c|c|}
\hline \multicolumn{7}{|c|}{ Coefficients $^{-\mathrm{a}}$} \\
\hline & \multicolumn{3}{|c|}{$\begin{array}{l}\text { Unstandardize } \\
\text { d Coefficients }\end{array}$} & \multirow{2}{*}{$\begin{array}{l}\text { Standar } \\
\text { dized } \\
\text { Coeffici } \\
\text { ents } \\
\quad \text { Beta }\end{array}$} & \multirow[b]{2}{*}{$\mathrm{t}$} & \multirow[b]{2}{*}{ Sig. } \\
\hline & Model & B & Std. Error & & & \\
\hline \multirow[t]{3}{*}{1} & (Constant) & .052 & .352 & & .149 & .882 \\
\hline & $\begin{array}{c}\text { Pedagogic } \\
\text { competency } \\
\text { (X1) }\end{array}$ & .975 & .068 & .839 & 14.387 & .081 \\
\hline & $\begin{array}{c}\text { Teacher } \\
\text { creativity }(\mathrm{X} 2)\end{array}$ & .113 & .064 & .103 & 1.766 & .000 \\
\hline
\end{tabular}

Based on the results of the T-test above, it appears that, obtained sig. for the influence of teacher pedagogical competence $(\mathrm{X} 2)$ is 0.081 . The value $>0.05$, it means that pedagogical competence does not significantly affect students' creative thinking abilities. The value of sig, for teacher creativity on students 'creative thinking abilities, is equal to $0,000<0.05$, which means that the mathematics teacher's creativity in teaching has a significant effect on students' creative thinking abilities.

Based on the data above, it can be understood that the three variables, namely pedagogical competence, teacher's creativity in teaching, and students' abilities in creative thinking are interrelated. Although in the next test that the students' creative thinking ability is more influenced by the teacher's creative ability in teaching than the teacher's pedagogical competence. This means that students 'creative thinking abilities can be improved if the mathematics teacher is more creative in implementing the learning process, while the teacher's pedagogical competence has an indirect effect on students' creative thinking abilities.

The difference in teacher pedagogic competence and teacher teaching creativity in influencing students' creative thinking ability can be understood considering pedagogic competence is the teacher's internal ability while the teacher's creativity in teaching is external ability so that it is more easily seen by students. This also proves that the emergence of creative thinking abilities comes from one's ability to make observations. In other words, a person's ability to think can grow and develop because of something that is seen, heard, felt so that it causes curiosity. Mardhiyana \& Sejati (2016) explained that through curiosity, learning is not just knowing but exploring to find out more so that it gives meaning to what is obtained in the learning process. Thus, teacher creativity in teaching can trigger curiosity and exploration power of students in learning, thus encouraging the growth of creative thinking abilities.
Given that the teacher's creativity in teaching directly influences students' creative thinking abilities, the teacher as an educator must be able to understand the various factors that influence the teacher's creativity itself. With their ability to understand these factors, it is expected that teachers will be able to optimize their potential so that it will have a positive impact on the development of students' creative thinking abilities. According to Sutrisno \& Siswanto (2016) factors that influence creativity are (1) situations that present incompleteness and openness, (2) situations that allow and encourage any questions, (3) situations that encourage producing something, (4) situations that encourage responsibility and independence, (5) situations that emphasize self-initiative, (6) bilingualism, (7) attention from parents, (8) stimulation from the school environment, (9) selfmotivation. Thus the creativity practiced by the teacher in the learning process is part of stimuli and situations that encourage the development of creative thinking skills in students. The pedagogic competence is an internal ability of the teacher, meaning that pedagogical competence plays a role in increasing teacher creativity, and teacher creativity plays a role in increasing student creativity.

The findings in this study provide information and thoughts that the teacher's role in arise the full potential of students, in this case, the ability to think creatively is very important (You, 2017). Therefore, in implementing mathematics learning teachers need to develop learning that encourages students to be more active. According to (Kenedi, 2017) active learning allows students to develop creative thinking skills. Also, teachers need to develop learning models that can potentially improve students' creative thinking skills. Some learning models that have the potential to develop students' creative thinking skills include STEM learning models (Ismayani, 2016), learning models with group investigation (Christina \& Kristin, 2016), guided inquiry learning models (Suryaningsih, Cahaya, \& Poerwati, 2016), project-based learning models (Titu, 2015), and the use of realistic mathematics learning (Wijayanti, 2016).

In addition to the use of varied learning models, enhancing student creativity can also be done by teachers, for example by developing learning tools that are oriented towards student creativity (Kusumaningrum \& Djukri, 2016), the use of certain learning media (Nurrita, 2018). Thus, the higher the teacher's creativity in carrying out the process of learning mathematics, the creative thinking ability of students will also develop.

\section{CONCLUSION}

Based on the data and discussion above it can be concluded that the pedagogical competence of teachers is dominated by the group with the category of "medium" as much as $65.6 \%$, the creativity of mathematics teachers in teaching is dominated by the group with the moderate category as much as $83.3 \%$ and the creative thinking abilities of students are at the low category, which is as much as $47.5 \%$. Based on the results of the T-test shows that, obtained sig. for the influence of teacher pedagogical competence $(\mathrm{X} 2)$ is 0.081 . The value $>0.05$, it means that pedagogical competence does not significantly affect students' 
creative thinking abilities. The value of sig, for teacher creativity on students 'creative thinking abilities, is equal to $0,000<0.05$, which means that the mathematics teacher's creativity in teaching has a significant effect on students' creative thinking abilities.

\section{ACKNOWLEDGMENTS}

This research has involved many parties, since the planning, implementation so that it came to the writing of reports and publications. To that end, the researchers would like to thank the mathematics learning development team with the Google classroom application for helping to adjust and compile teaching materials so that research can be carried out. The researchers also thanked the Principal of SMA 6 Muaro Jambi, who had supported this research.

\section{REFERENCES}

Alghifari, E. S., Sunandar, S., Yuliejantiningsih, Y., Nurkolis, N., Putri, N., Asri, Y., ... Sunanik. (2016). Manajemen Mutu Dalam Pengembangan Kompetensi Guru (Studi pada Madrasah Aliyah Negeri di Kota Sragen). Tarbawi: Jurnal Keilmuan Manajemen Pendidikan. https://doi.org/10.32729/edukasi.v10i3.169

Anggoro, B. S. (2015). Pengembangan Modul Matematika Dengan Strategi Problem Solving untuk Mengukur Tingkat Kemampuan Berpikir Kreatif Matematis Siswa. Al-Jabar: Jurnal Pendidikan Matematika.

Azhari, A., \& Somakim, S. (2014). Peningkatan Kemampuan Berpikir Kreatif Matematik Siswa Melalui Pendekatan Konstruktivisme Di Kelas Vii Sekolah Menengah Pertama (SMP) Negeri 2 Banyuasin III. Jurnal Pendidikan Matematika. https://doi.org/10.22342/jpm.8.1.992.1-12

Christina, L. V., \& Kristin, F. (2016). Efektivitas Model Pembelajaran Tipe Group Investigation (GI) Dan Cooperative Integrated Reading And Composition (Circ) Dalam Meningkatkan Kreativitas Berpikir Kritis Dan Hasil Belajar IPS Siswa Kelas 4. Scholaria: Jurnal Pendidikan Dan Kebudayaan. https://doi.org/10.24246/j.scholaria.2016.v6.i3.p217-230

Fakhriyani, D. V. (2016). Pengembangan Kreativitas Anak Usia Dini. Wacana Didaktika. https://doi.org/10.31102/wacanadidaktika.4.2.193-200

Febriandar, E. I. (2018). Pengaruh Kreativitas Guru Dalam Menerapkan Ice Breaking Dan Motivasi Belajar Terhadap Hasil Belajar Siswa Sekolah Dasar. Briliant: Jurnal Riset Dan Konseptual. https://doi.org/10.28926/briliant.v3i4.253

Habibullah, A. (2012). Kompetensi Pedagogik Guru. EDUKASI: Jurnal Penelitian Pendidikan Agama Dan Keagamaan. https://doi.org/10.32729/edukasi.v10i3.169

Hadi, S. (2018). Pengaruh Kompetensi Pedagogik Dan Kompetensi Profesional Terhadap Kinerja Guru Bimbingan Dan Konseling Di SDLB Kota Bandung. Jurnal Ilmu Politik Dan Komunikasi. https://doi.org/10.34010/jipsi.v8i1.877
Ismayani, A. (2016). Pengaruh Penerapan STEM Project - Based Learning terhadap Kreativitas Matematis Siswa SMK. Indonesian Digital Journal of Mathematics and Education. https://doi.org/2407-8530

Juandi, A., \& Sontani, U. T. (2017). Keterampilan Dan Kreativitas Mengajar Guru Sebagai Determinan Terhadap Prestasi Belajar Siswa. Jurnal Pendidikan Manajemen Perkantoran. https://doi.org/10.17509/jpm.v2i2.8114

Juhji. (2016). Guru, mendidik, mengajar, nilai, pembentukan kepribadian, panutan. Studia Didaktika.

Kau, M. A. (2017). Peran Guru Dalam Mengembangkan Kreativitas Anak Sekolah Dasar. Proceeding Seminar Dan Lokakarya Nasional Revitalisasi Laboratorium Dan Jurnal Ilmiah Dalam Implementasi Kurikulum Bimbingan Dan Konseling Berbasis Kkni.

Kenedi. (2017). Pengembangan Kreativitas Siswa dalam Proses Pembelajaran di Kelas II SMP Nergeri 3 Rokan IV Koto. Jurnal Ilmu Pendidikan Sosial, Sains, Dan Humaniora.

Kurniawan, A., \& Astuti, A. P. (2017). Deskripsi kompetensi pedagogik guru dan calon guru kimia sma muhammadiyah 1 semarang 1),2). Seminar Nasional Pendidikan, Sains Dan Teknologi.

Kusumaningrum, S., \& Djukri, D. (2016). Pengembangan perangkat pembelajaran model project based learning (PjBL) untuk meningkatkan keterampilan proses sains dan kreativitas. Jurnal Inovasi Pendidikan IPA. https://doi.org/10.21831/jipi.v2i2.5557

LAMBOK SIMAMORA. (2014). Pengaruh Persepsi Siswa Tentang Kompetensi Pedagogik Guru Dan Kebiasaan Belajar Siswa. Jurnal Formatif 4(1): 21-30, 2014 ISSN: 2088-351X. https://doi.org/http://dx.doi.org/10.30998/formatif.v4i1.136

Mardhiyana, D., \& Sejati, E. O. W. (2016). Mengembangkan Kemampuan Berpikir Kreatif dan Rasa Ingin Tahu Melalui Model Pembelajaran Berbasis Masalah. PRISMA, Prosiding Seminar Nasional Matematika.

Moma, L. (2016). Pengembangan Instrumen Kemampuan Berpikir Kreatif Matematis Untuk Siswa Smp. Delta-Pi: Jurnal Matematika Dan Pendidikan Matematika.

Monawati., M., \& Fauzi., F. (2018). Hubungan Kreativitas Mengajar Guru Dengan Prestasi Belajar Siswa. Jurnal Pesona Dasar. https://doi.org/10.24815/pear.v6i2.12195

Musrikah, M. (2018). Higher Order Thingking Skill (Hots) Untuk Anak Sekolah Dasar Dalam Pembelajaran Matematika. Martabat: Jurnal Perempuan Dan Anak. https://doi.org/10.21274/martabat.2018.2.2.339-360

Noer, S. H. (2013). Kemampuan Berpikir Kreatif Matematis Dan Pembelajaran Matematika Berbasis Masalah Open-Ended. Jurnal Pendidikan Matematika. https://doi.org/10.22342/jpm.5.1.824. 
Nuriadin, I., \& Perbowo, K. S. (2013). Analisis Korelasi Kemampuan Berpikir Kreatif Matematik Terhadap Hasil Belajar Matematika Peserta Didik SMP Negeri 3 Lurangung Kuningan Jawa Barat. Infinity Journal. https://doi.org/10.22460/infinity.v2i1.25

Nurjannah, Z., \& Irma, A. (2019). Pengaruh Penerapan Model Pembeljaran Creative Problem Solving Terhadap Kemampuan Berpikir Kreatif Matematis Ditinjau Dari Kemandirian Belajar Siswa SMP Negeri 40 Pekanbaru. JURING (Journal for Research in Mathematics Learning). https://doi.org/10.24014/juring.v1i3.4776

Nurrita, T. (2018). Pengembangan Media Pembelajaran Untuk Meningkatkan Hasil Belajar Siswa. Misykat.

Purnamawanti, C., Suliswiyadi, S., \& Nugroho, I. (2018). Pengaruh Kompetensi Pedagogik Guru Kelas Terhadap Hasil Belajar IPA di MI Muhammadiyah Kalibanger Kabupaten Temanggung. https://doi.org/10.31603/tarbiyatuna.v9i1.2088 Tarbiyatuna.

R.M, M. (1994). Kreativitas. Mudra (JURNAL SENI BUDAYA).

Rahman, A. M., Mutiani, M., \& Putra, M. A. H. (2019). Pengaruh Kompetensi Pedagogik Dosen terhadap Motivasi Belajar Mahasiswa Pendidikan IPS. Jurnal Darussalam: Jurnal Pendidikan, Komunikasi Dan Pemikiran Hukum Islam. https://doi.org/10.30739/darussalam.v10i2.380

Rahmazatullaili, R., Zubainur, C. M., \& Munzir, S. (2017). Kemampuan berpikir kreatif dan pemecahan masalah siswa melalui penerapan model project based learning. Beta Jurnal Tadris Matematika. https://doi.org/10.20414/betajtm.v10i2.104

Rasuli, A., \& Rivaie, W. (2013). Kompetensi Pedagogik Guru Dalam Meningkatkan Hasil Belajar Siswa Mata Pelajaran Sosiologi. Jurnal Pendidikan Dan Pembelajaran.

Sagitasari, D. A. (2010). Hubungan Antara Kreativitas dan Gaya Belajar dengan Prestasi Belajar Matematika Siswa SMP. Universitas Negeri Yogyakarta.

Sambada, D. (2012). Peranan Kreativitas Siswa Terhadap Kemampuan Memecahkan Masalah Fisika Dalam Pembelajaran Kontekstual. Jurnal Penelitian Fisika Dan Aplikasinya (JPFA). https://doi.org/10.26740/jpfa.v2n2.p3747

Sappaile, N. (2017). Pengaruh Kompetensi Pedagogik , Kompetensi Profesional, dan Sikap Profesi Guru Tehadap Kinerja Penilaian Guru di Sekolah Dasar. Jurnal Teknologi Pendidikan. https://doi.org/10.1080/08897077.2014.993491
Siswono, T. Y. E. (2004). Mendorong Berpikir Kreatif melalui Pengajuan Maslah (Problem Posing). Journal of Mathematics Education.

Sugilar, H. (2013). Meningkatkan Kemampuan Berpikir Kreatif Dan Disposisi Matematik Siswa Madrasah Tsanawiyah Melalui Pembelajaran Generatif. Infinity Journal. https://doi.org/10.22460/infinity.v2i2.32

Supranoto, H. (2015). Penerapan Lesson Study Dalam Meningkatkan Kompetensi Pedagogi Guru Sma Bina Mulya Gadingrejo Tahun Pelajaran 2015/2016. PROMOSI (Jurnal Pendidikan Ekonomi). https://doi.org/10.24127/ja.v3i2.330

Supriyono, A. (2017). Pengaruh Kompetensi Pedagogik, Profesional, Dan Motivasi Kerja Terhadap Kinerja Guru Sekolah Dasar. Jurnal Pendidikan. https://doi.org/10.33830/jp.v18i2.269.2017

Suryaningsih, N. M. A., Cahaya, I. M. E., \& Poerwati, C. E. (2016). Implementasi Pembelajaran Inkuiri Terbimbing Berbasis Permainan Dalam Meningkatkan Kreativitas Anak Usia Dini. JPI (Jurnal Pendidikan Indonesia). https://doi.org/10.23887/jpi-undiksha.v5i2.8559

Sutrisno, V. L. P., \& Siswanto, B. T. (2016). Faktor-Faktor Yang Mempengaruhi Hasil Belajar Siswa Pada Pembelajaran Praktik Kelistrikan Otomotif Smk Di Kota Yogyakarta. Jurnal Pendidikan Vokasi. https://doi.org/10.21831/jpv.v6i1.8118

Tambunan, N. (2016). Pengaruh Strategi Pembelajaran dan Minat Belajar Terhadap Kemampuan Berpikir Kreatif Matematis Siswa. Formatif: Jurnal Ilmiah Pendidikan MIPA. https://doi.org/10.30998/formatif.v6i3.993

Titu, A. M. (2015). Penerapan Model Pembelajaran Berbasis Proyek untuk Meningkatkan Kreatifitas Siswa pada Materi Konsep Masalah Ekonomi. Prosiding Seminar Nasional.

Wahyuni, A. (2013). Pengembangan Kreativitas Guru Sebagai Modal Penerapan Kurikulum 2013. Proseding Seminar Nasional Pendidikan : Guru Kreatif Kunci Sukses Pendidikan Berkemajuan. https://doi.org/10.1007/s00436-012-2902-1

Wijayanti, S. (2016). Penggunaan Pendekatan Realistic Mathematics Education (Rme) Sebagai Upaya Peningkatan Kreativitas Dalam Pemecahan Masalah Matematika Siswa Kelas X.7 Sma Negeri 1 Pulokulon. Magistra.

Wulandari, D. (2012). Pengaruh Kompetensi Pedagogik dan Kompetensi Profesional Guru terhadap Economic Literacy melalui Prestasi Belajar Siswa Kelas XII IPS di SMA Kota Malang. Jurnal Pendidikan Humaniora. 